\title{
Rapid Change versus Long-Term Social Change during the Neolithic-Chalcolithic Transition in Central Anatolia
}

\author{
Peter F. Biehl ${ }^{\mathrm{a}}$ \\ ${ }^{a}$ Department of Anthropology, College of Arts and Sciences, State University of New York at Buffalo, 380 MFAC-Ellicott Complex Buffalo, NY 14261 - \\ 0005 , USA
}

\section{ARTICLE INFO}

\section{Article history:}

Received: 31 May 2012

Accepted: 29 August 2012

\section{Keywords:}

Neolithic

Anatolia

climate and culture change

Çatalhöyük

\begin{abstract}
$A B S T R A C T$
The paper scrutinizes the process of cultural, social, economic and symbolic transition between the Neolithic and Chalcolithic in Central Anatolia as revealed at the Çatalhöyük East and West Mounds. It will discuss both rapid change and long-term social and palaeo-environmental changes in the Konya plain and will examine how humans responded to the climate change that occurred during the " $8.2 \mathrm{k}$ cal BP climate event". The key hypothesis is that the change in climate and environment caused people to move westwards into Western Anatolia and across Europe. Çatalhöyük offers a microcosm that may help us unlock some of the key questions surrounding this time period. At Çatalhöyük, settlement shifted from the East to the West Mound at exactly this time. The two tell sites sitting side by side offer the exceptional chance to analyse human responses to this event on a micro-scale and give us the possibility to answer the question of why and how does the shift from the East to the West Mound take place at this time. Once we understand the regional process, we can widen our lens and try to determine the broader effects the shift had. The paper will also re-evaluate these changes within a framework of agency and materiality theories and contextualize the events at Çatalhöyük at the turn of the $7^{\text {th }}-6^{\text {th }}$ millennium cal BC with other sites in the Near East.
\end{abstract}

\section{Introduction}

We often justify our work through our ability to investigate deep time on a scale no other approach can offer. But explanations of long-term change have almost always been relatively reductionist and functionalist. Theoretically sophisticated approaches have concentrated on tightly focused studies rather than on long-term, geographically broad studies. Even when several areas are compared and many centuries are encompassed, processual and postprocessual works have tended to treat the past as a series of patterns rather than in terms of true transformations, avoiding questions of both contemporaneity and causation and consequently of the relations between change, culture, economy, politics, demography and environment.

How can we expand from studies of individual societies into regional views and diachronic analyses? And how do we theorize the human world on the scales of millennia?

\footnotetext{
"Corresponding author. E-mail: pbiehl@buffalo.edu
}

In this article, I will reconsider research on rapid change as well as long-term change and will discuss how these ideas can improve our understanding of the constitutive changes during the turn of the $7^{\text {th }}$ to the $6^{\text {th }}$ millennium cal BC during the Neolithic-Chalcolithic transition in Central Anatolia. I will focus on the concepts of change and continuity both regarding social and climate change as well as on social interaction and reproduction and suggest how the previous research on the topic can be taken forward. Here, I will use one example - Çatalhöyük in Central Anatolia - to demonstrate the importance of using and linking micro- and macro-scale archaeological analysis in both dimensions time and space. I will highlight that the problem with large-scale analyses is especially pertinent if we are trying to use an agency-based approach as succinctly demonstrated in Marek Zvelebil's seminal article on "Homo Habitus" (Zvelebil 2005b).

\section{Rapid and long term change: theory and models}

A good starting point for a discussion of theories and models on cultural and environmental change is Zvelebil's statement 
that "at a regional and community level of discourse and decision-making, individual and collective motivations reasons and justifications for doing things - must have been formulated into strategies by people who had a certain level of knowledge about their social and natural environment" (Zvelebil 2005b, 88). For the methodological framework for a "broad application of structuration theory [that] helps comprehension of this complex process of discourse and strategic implementation of decisions" (ibd., 88) he outlines the following eight research areas: structural conditions, structural principles, routine practice or habitus, agency, historical constraints, tradition and social memory, and cultural inheritance and intergenerational transmission of knowledge (ibd., 88-89). Though Zvelebil focuses in this article on the origins of the Neolithic and spread of early farming on a broad, inter-regional scale he is also interested in the question of what was the motivation for such a sociocultural and economic change at a local and regional level and whether causes and motivations operating at the regional level may well have differed from the more general and diffuse conditions operating at broader geographical scales? (ibd., 87-88)? Also Dobres and Robb have suggested to think in terms of plans, intentions, ideas, projects and experiences, which happen in a few years, a decade or two - in the time of human life spans (Dobres, Robb 2005). But the question still remains how can we expand from studies of individual societies into regional views and diachronic analyses?

Andrew Sherratt's interactionist approach is one way to study long-term change. In his seminal paper, "Reviving the Grand Narrative: Archaeology and Long-Term Change," he laid out his approach and emphasized the importance of technology, subsistence and consumption as well as social interaction and cultural encounter (Sherratt 1995). In another paper "Envisioning global change: A long-term perspective" he has discussed his non-reductionist conception of longterm change in more detail and exemplified the processes involved with case studies from around the world. In both papers Sherratt's premise is simple: "Putting culture back into society may well be the most crucial operation in providing a realistic description of long-term change" (ibd., 3 ); and "time and space are the dimensions of the process to be studied" (Sherratt 2000). He identified two related factors for the current lack of thinking about the large scale and long term: "the genuine faults of the last attempt (social 'evolutionism') and the wider contemporary dissatisfaction with any kind of thinking on this scale" (ibd., 4).

Can this be done without resorting to environmental or cultural determinism, which has so often been bemoaned? In many processual models, which took demography and environment seriously, one just assumed, on the one hand, the short-term, and particularly human symbolic behavior was the realm of proximate cause - interesting and colorful, but essentially unimportant to the ultimate causal forces operative in the long-term. Sherratt has stressed "the importance both of antecedent conditions and of geographical realities in understanding the character of social change" (Sherratt $2000,5)$. But his interactionist approach is not intended to supplant other, richer and more subtle genres of history and anthropology, dealing with events and structures on a human scale: indeed, it specifically acknowledges their priority.

An example of this is the spread of farming in the Neolithic (see also Zvelebil 2005a, 183-190; Sagona, Zimansky 2009, 122-124). "The paradox of the Neolithic is that it was indeed a 'total package', in that cereal-cultivation was associated with a coherent set of social and material practices (and their mental correlates, of which house-building and the acquisition of portable items from long distances were essential aspects" as Sherratt summarized in "Settling the Neolithic: a digestif" (2005, 144). He continues that "the tendency of farming populations to multiply (over the long term) was thus only one aspect of the Neolithic dynamic; another was the elaboration of material culture both in static and portable form, and in the interaction between them" (ibd., 144). Once farming was in existence, the process of cultural change was reinforced by features, which accompanied it: larger communities, increased sedentism and the associated arts of architecture, pottery, textile production and stone-working. This horticultural complex spread from the Near East westward over the Mediterranean and temperate Europe, and eastward through Iran and to western India (Sherratt 2005). In this model the explanation depends on the long-term accumulative effects of demographic shifts and environment. But what about long periods of stability as well as rapid change?

It is true that gradualistic demographic and environmental processes can have dramatic long-term effects, but we cannot regard either human population or resource use as independent forces, which happen without the influence of social relations and cultural ideas. Building upon the French historian Braudel's temporalities (Braudel 1969) Audouze and Valentin have suggested a ternary division of time adapted to the Prehistoric Period which is composed of a very short term (temps très bref - shorter than Braudel's temps courts) from minutes to months, a very long term (longue époques - shorter than Braudel's longue durée) spanning from centuries to millennia, and in between the intermediate periods (temps intermédiare or périodes intermédiare) which includes Braudel's conjuncture, and spans from seasons to centuries (Audouze, Valentin 2010, 35). But in the same book, Graeme Barker pointed out that "one of the main criticisms of Braudel was that he failed to demonstrate how his three different temporalities and fourth dimension (ideology) actually interacted with and affected each other to create history" (Barker 2010, 220). He identifies "the failure of the processual agenda to engage with individual actors and their role in maintaining or changing the social order, and its reliance on functional efficiency as a prime motor of change; and the failure of the post-processual agenda to lift its gaze from the machinations of the individual actors and notice the longue durée's big shadow falling over them from time to time. When, how, and why do small-scale actions combine to create significant social transformations?" (Barker 2010, 221).

Kristian Kristiansen and Thomas Larsson have pointed out that it is especially the dynamic relationship between long-term tradition and short-term transformation and their 
internal articulation that we need to study. However, agency without social and institutional frameworks is abstract and creates agents without motivation and direction - with the unwarranted effect of leaving too much scope for creative interpretations to fill the gaps. Self and identity, agency and innovation, can only be properly understood against a background of tradition and the socializing role of institutions - "or in Sassaman's words, 'normative structures are longterm derivatives of agency"” (Kristiansen, Larsson 2007).

And finally, Bayesian modelling of radiocarbon data is becoming more common in archaeology (see, e.g. Bayliss et al. 2007; Whittle et al. 2010; 2011) which promises in Alasdair Whittle's words "the possibility of building chronological models with precision to the scales of lifetimes and even generations" (Whittle et al. 2010, 71) that "will change our view of those 'general trends', which have so far been our staple" (Whittle et al. 2010, 84).

To summarize, if we want to research rapid as well as longterm change productively in archaeology - and if we want to paint large-scale pictures, which are also about people - we need to incorporate agency theory in order to understand the relationship between human action in the short term and change in the long term. It seems clear that the effect of different factors depends to some extent on time scales. "Rapid" change, culturally as well as environmentally, seems to occupy a time horizon of a few decades. People must have been conscious of a changing world around them and of having to change, innovate or adapt their habits and practices. In contrast, sociopolitical as well as economic-technological or religioussymbolic changes seem to unfold over a longer time span of generations to centuries. It is the linkages between shortterm and long-term change that we need to investigate from the micro to the macro level including all spheres of human activity and interaction: from the cultural to the environmental and from the societal to political, economic, technological and religious-symbolic spheres.

\section{Social and environmental change at the transition from the Neolithic to the Chalcolithic in Central Anatolia}

In the following I will discuss a case study, which demonstrates how important it is to include and link the micro- and macro scale analysis on the one hand, and to add agency theory, on the other hand, in order to better understand and contextualize rapid and long-term change.

In our recent excavations at the Late Neolithic and Early Chalcolithic (ca. 6000-5600 cal BC) West Mound at Çatalhöyük (Figure 1 and Figure 2) we are scrutinizing
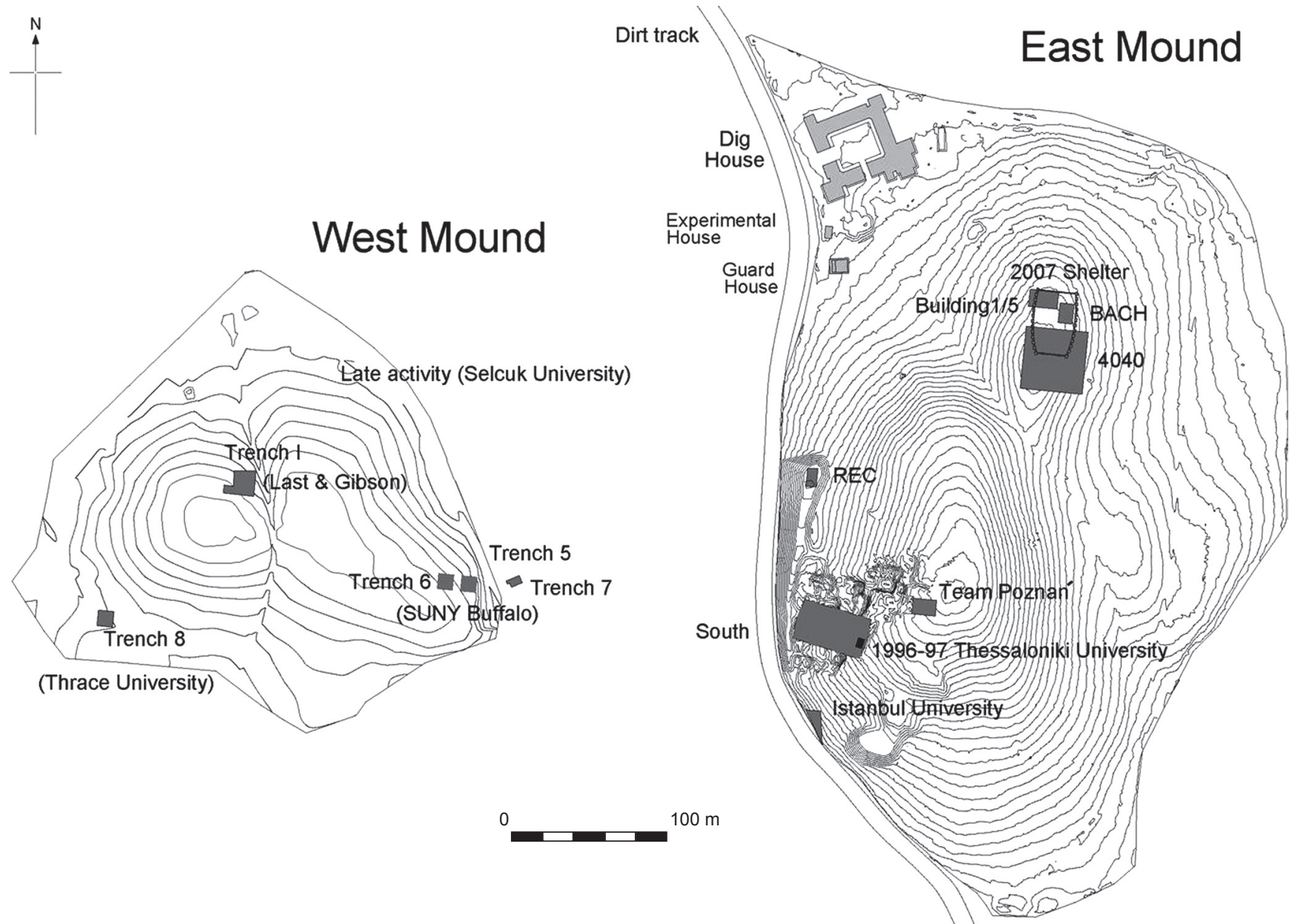

Figure 1. Site plan with the excavations on the East and West Mounds. 


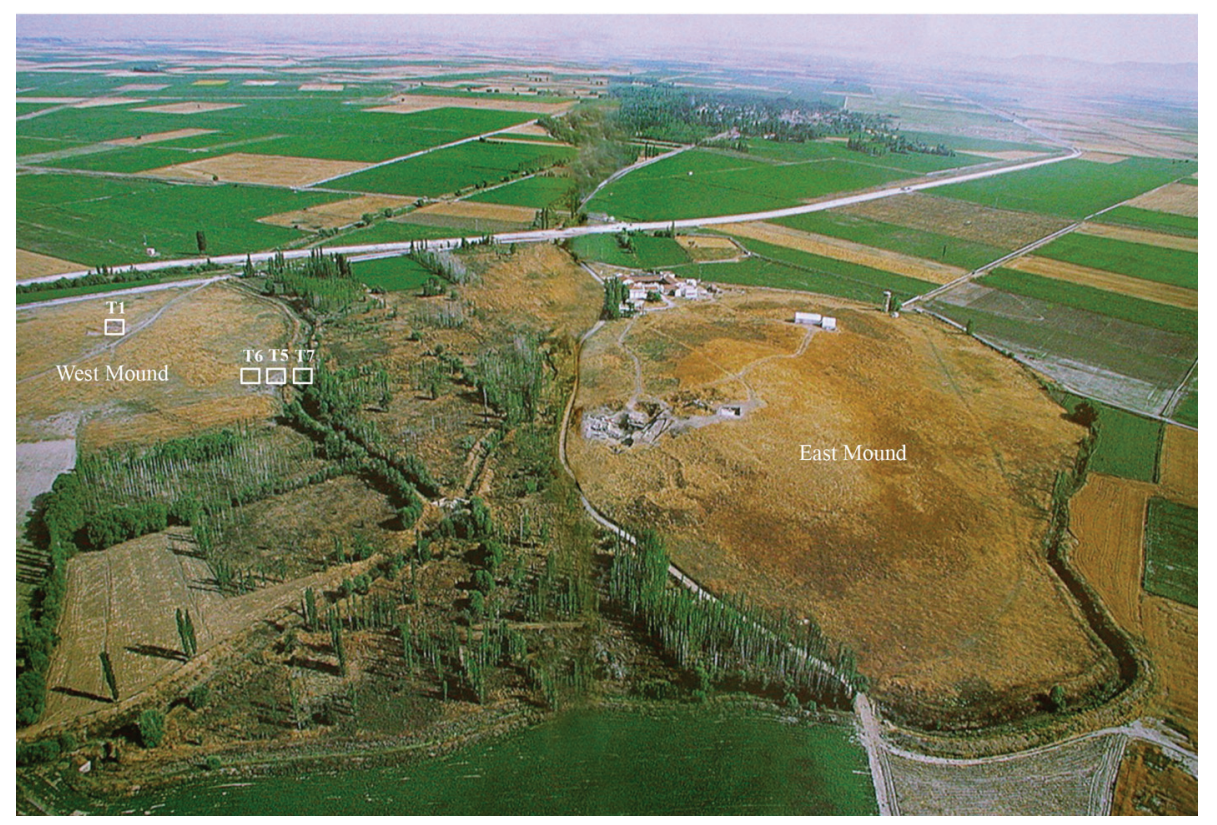

Figure 2. Aerial Photo of the Çatalhöyük East and West Mounds with the excavation trenches (Trench 8 is not on the photo; see Figure 1).

the process of cultural, social, economic and symbolic transition between the Neolithic and the Chalcolithic in Central Anatolia. This research situates the transition in the palaeo-environmental changes in the Konya plain and presents a preliminary interpretation of the social changes and continuities between the East and West Mound at Çatalhöyük around 6000 cal BC (Biehl in press; Biehl et al. 2012). We also ask how humans respond to possible climate and environmental change as it plays a crucial part in the formation of society. When climate changes, societies react by either adapting or transforming. In our case study, the question is how the people at Çatalhöyük responded to the climate change that seemed to have occurred during the so-called " $8.2 \mathrm{k}$ cal BP climatic event" in Central Anatolia (Weninger et al. 2006; Biehl, in press; Biehl, Niewenhuyse, in press). The key hypothesis is that the rapid change in climate and environment caused people to move in the long term westwards into Western Anatolia and Southeast Europe - and eventually across Europe (Biehl, Rosenstock 2009; Biehl at al. 2012). Çatalhöyük offers a microcosm that may help us unlock some of the key questions surrounding these "Times of Change" which have been recently discussed at an international conference with the same title in Berlin (Biehl, Rosenstock 2012). Beside the climate change model the question of the so-called "Second Neolithic Revolution" (Düring 2010: 122-125) was discussed with case studies ranging from the Persian highland and the Syrian plains to the whole of Anatolia and the Aegean and the Balkans. Though the possible impact of the 8.2 event on communities in the Near East and Southeastern Europe after 6200 BC can only be considered as one of many possible triggers for culture change around $6000 \mathrm{BC}$ it has to be highlighted that at Çatalhöyük settlement shifted from the East to the West Mound at around this time. The two tell sites sitting side by side offer an exceptional chance to analyse human rapid and long term responses to this event on a micro-scale and may give us the possibility to answer the question of why and how does the shift from the East Mound to the West Mound take place at this time. Once we understand the regional process, we can widen our lens and try to determine the broader effects the shift had on the Near East and Europe. We have either a complete collapse of settlements around 6000 BC as in the Syrian site of Shir (Bartl, in press) or some sort of hiatus as in Mersin-Yumuktepe/Turkey (Caneva, in press) or the phenomenon of re-locating settlements as in Khirokitia/Cyprus (Le Brun et al., in press), Sabi Abyad/ Syria (Nieuwenhuyse, in press) and Çatalhöyük (Biehl in press, Biehl et al. 2012). Several changes seemed to have already been under way well before $6200 \mathrm{BC}$ at some of the discussed sites and could have been helpful pre-adaptations for the climatic event and its supposedly materialization as "innovations" during the event which lasted ca. 180 years (Biehl, Rosenstock 2012: 30).

The new evidence from Çatalhöyük suggests some effects of this event on both the East and West Mound and places the gradual move from East to West in this short time frame starting shortly after $6200 \mathrm{cal} \mathrm{BC}$ and ending between 6000 and $5900 \mathrm{cal}$ BC. Though we have a deep and secure stratigraphy for the beginning of the settlement of the West Mound (Biehl et al. 2012, 6-61, Fig. 5) the evidence for the end of the East Mound settlement is more problematic. Boyer and Roberts have argued that layers between 2 and $3 \mathrm{~m}$ are eroded from the top of the East Mound (Boyer et al. 2006) and we might not be able to understand and reconstruct the latest levels of the East Mound settlement. However, there are changes and fundamental differences between the typical East Mound and West Mound architecture (Figure 3). The architecture in the upper occupation layers of Levels I and 0 on the East Mound already suggest continuity of occupation alongside rapid social and economic developments taking place after $6200 \mathrm{cal}$ BC (Marciniak, Czerniak 2007). It would seem to be no coincidence that a decline in the symbolic elaboration of houses occurs 
Figure 3. Structural comparison between the architectural layout of (a) building 98 of the West Mound (Trench 5; 3D photos by Patrick $T$ Willett) and (b) buildings of the Çatalhöyük East Mound (Photo by the author). (a)

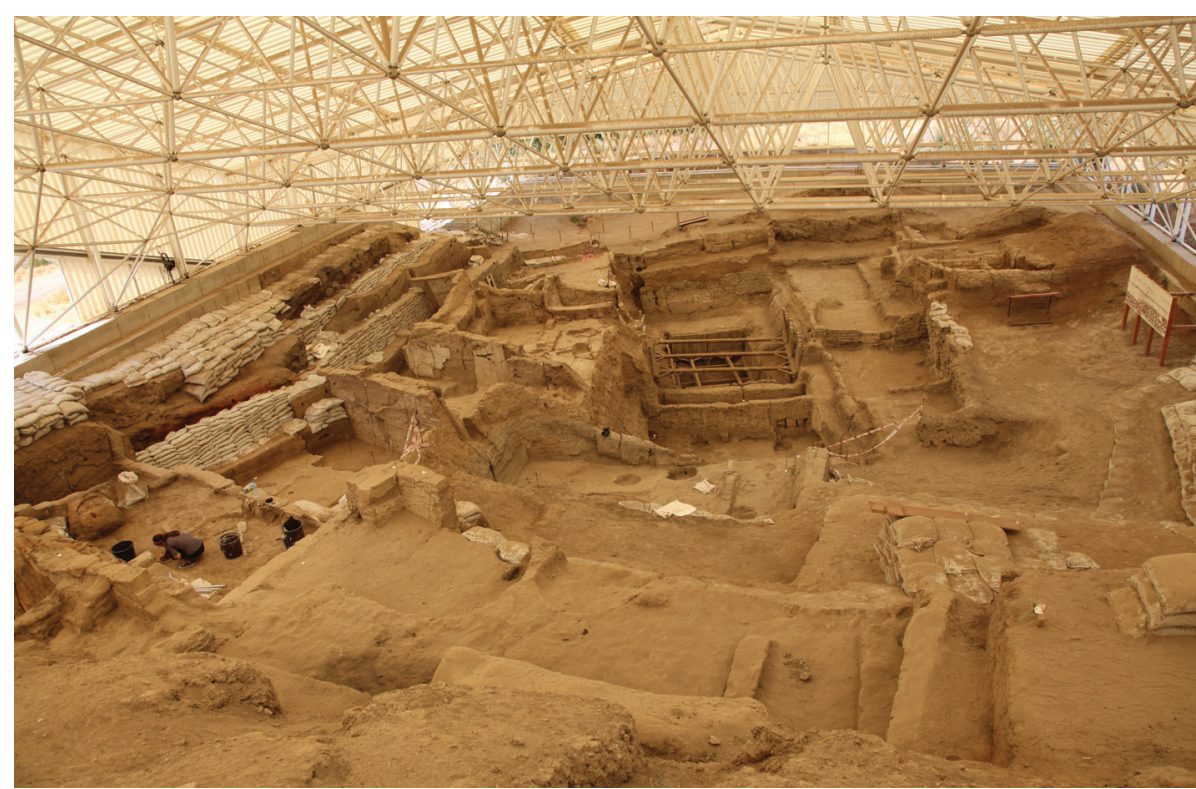

(b)

alongside a more functional division of household space, an increase in the quantity and complexity of portable artifacts (especially pottery) and the development of a more integrated settlement system on the Konya Plain.

The similarities with roughly contemporary Can Hasan I layer $2 \mathrm{~B}$ are striking, not only in the overall layout, orientation and dimensions of the buildings (Biehl et al. 2012, 57) (Figure 4). The internal buttresses are a common characteristic of architecture of the $6^{\text {th }}$ millennium BC not only in Central Anatolia. If we accept that climate influences architecture and building materials, we can also see this construction further in the west, where we find mudbrick architecture on stone foundations - e.g. in Hacilar I and Kuruçay 7 in the Lake District - and related architectural patterns with internal buttresses can be seen in Aktopraklık and
Ilıpınar in the Marmara region and even in Greece at Otzaki and Tsangli, the eponymous site for the Tsangli house type (Biehl et al. 2012: 57). Eva Rosenstock has demonstrated in a recent study that the geographical and climatic preferences of people together with the ecological conditions determine certain types of architecture (mudbrick and timber) at tells. She points out that "combining this picture and the correlation between the distribution of tell settlements and mud architecture with precipitation, temperature and aridity as well as terra rossa and terra fusca soils, it is possible to outline a possible scenario as to how ecological conditions favored the development of tells in Neolithic south-eastern Europe" (Rosenstock 2009).

What does this tell us about the problem of longterm change? First, it lets us reject a simple determinism. 


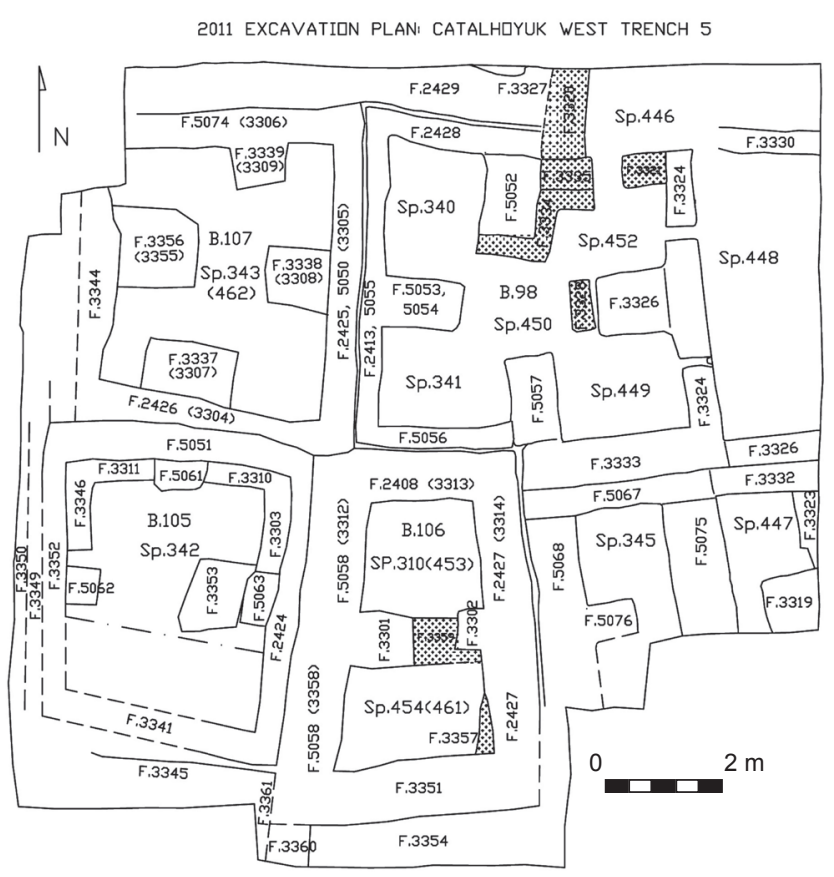

(a)

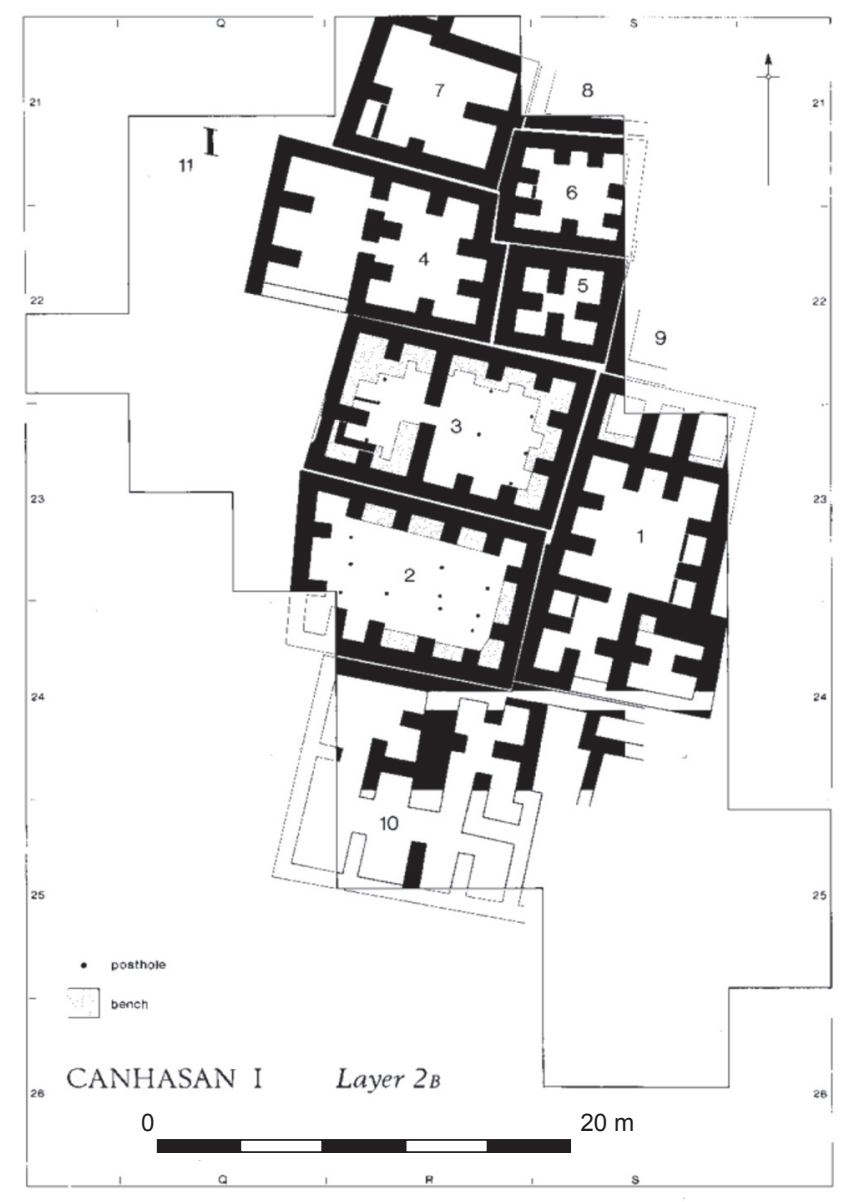

(b)

Figure 4. Structural Comparison between the architectural layout in (a) Trench 5 of the Çatalhöyük West Mound and (b) Can Hasan I layer 2B (after French 1998).
Geography and environment were important. Or the crucial role of "alluvial environments" and travel routes along valleys, which structured chains of trade and exchange. But basic environmental parameters were often shaped by human action including the connection of the fertile land with the mountainous region in terms of localized resources such as clay, salt and stone. As in the tell example, the people who lived on tell settlements possibly expressed their identities through the architecture and the agency of the prominent settlement mound in the landscape is even more obvious. Architecture and settlement type were determined by ecological as well as by social and symbolic factors and played an integral role in social interaction and reproduction creating a long-term history, in which the symbolic focus of social integration was shifting (see also During, Marciniak 2006). It is beyond the scope of this paper to discuss the phenomenological as well as functional aspects of living with the ruins of the glorious past of the settlement on the East Mound at Çatalhöyük but its agency must have lasted throughout the history of this community in the Konya plain (Figure 5).

Beyond the site of Çatalhöyük, further evidence of differences during this time period comes from the Konya Plain Survey project, which has discovered at least 14 contemporary but smaller sites within $20 \mathrm{~km}$ of the West Mound at Çatalhöyük, contrasting with the preceding period when the East Mound appears to have existed virtually in isolation (Baird 2002, 149; see also Baird 2006; Biehl 2012, 20; Düring 2010, 120). It seems that Çatalhöyük remained a dominant site but at the time of the West Mound occupation it lay within a dispersed settlement network, with relationships between neighboring sites to some extent reflected in their ceramic assemblages. This provides a clue to the quantitative abundance and quality of forms and designs of painted pottery, which must have had an important role in articulating the relationships between these sites - and with more farflung communities beyond the Konya Plain.

So does it matter whether the West Mound at Çatalhöyük is "Neolithic" or "Chalcolithic"? I do not think so. The radiocarbon evidence that Early Chalcolithic I begins before 5800 cal BC puts it firmly within the span of the "Neolithic" anywhere else. It would therefore seem sensible to resist use of the misleading term "Chalcolithic" for Çatalhöyük West and rather than representing a separate "Chalcolithic" occupation following a hiatus, allowing the site to be comfortably ignored in interpretations of the Çatalhöyük sequence, I suggest the West Mound is an integral part of that sequence, evidence for a coherent set of developments at the turn of the $6^{\text {th }}$ millennium, associated with changing ways of life and new contacts across and beyond the Konya Plain (Biehl 2012).

The main problem, however, remains the question of whether we have rapid or long term change at the NeolithicChalcolithic transition around $6000 \mathrm{cal} \mathrm{BC}$ in Çatalhöyük and Central Anatolia?

I think we have evidence for both. Starting around 6500 cal BC, after ca. 300 years of gradual social change (Düring 2010; Hodder 2006), transformed ca. 200 years of rapid 
Figure 5. Illustration of the aftermaths of change around $6000 \mathrm{cal} \mathrm{BC}$ at Çatalhöyük (Illustration Mesa Schumacher, copyright Peter F. Biehl).

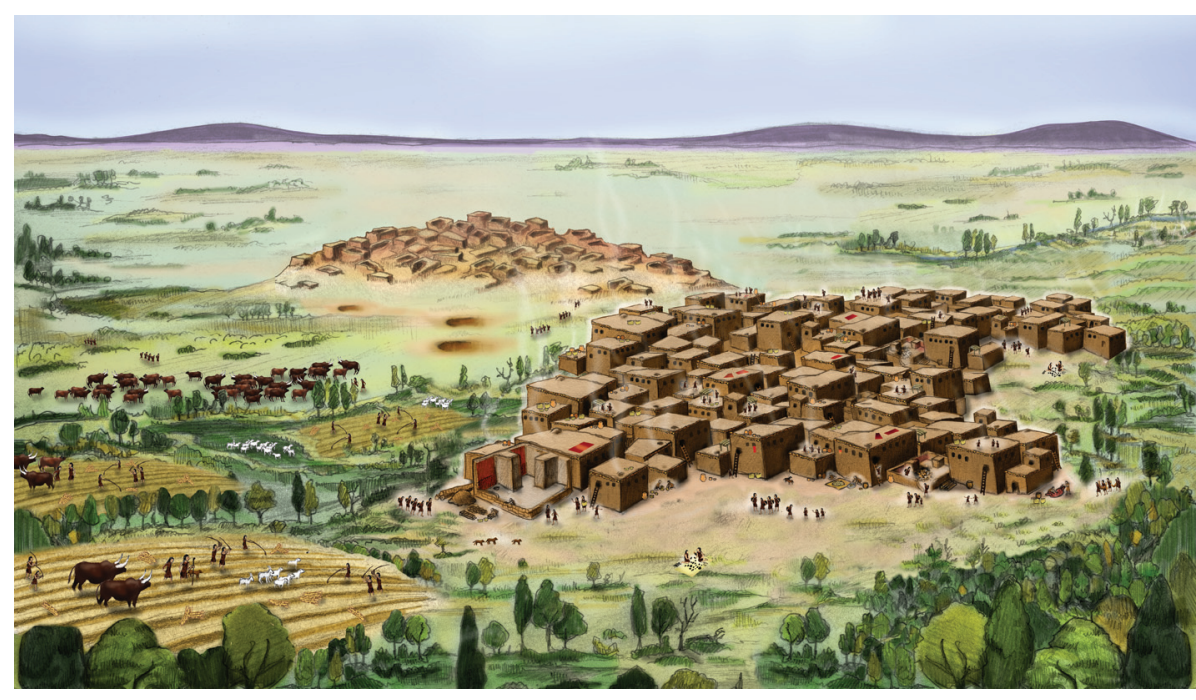

social change accompanied by climate and environmental change which eventually lead to the abandonment of the East Mound at around $6000 \mathrm{cal} \mathrm{BC}$ and after another ca. 500 years of gradual change in all spheres including the environment not only the abandonment of the West Mound but also the whole Konya plain.

I am intrigued by Ian Hodder's succinct application of entanglement theory for the explanation of change on a micro-scale at Çatalhöyük (Hodder 2010) and cannot agree more with his recent statement that "humans are not [alone] at the center of social change. Things too, as they fall apart and have their own interactions and dependencies enter into social change; and that change partly comes about through unintended, contingent, accidental interactions" (Hodder 2011: 182). Elsewhere we have discussed in detail the interdependency of human agency and climate as well as cultural change on the macro-level around 6000 cal BC in several aspects of material culture and economy, e.g. some pottery forms, worked bone, obsidian and botanical evidence, these only serve to emphasize the scale of the changes in other areas (Biehl et al. 2012) (Figure 6). Climate change also occurs at varying speeds - over millennia, over centuries, or sometimes within decades. It is natural that people would remember the change that happened the most abruptly, either in their lifetime or in the lifetime of the approximately three generations of people they know. Memories will naturally be stronger of events that caused the greatest hardship. People are most likely to respond to predictable change by regulating subsistence strategies, mobility, and other means of coping, e.g. to move the settlement closer to a diverting Çarşamba river. I believe that all these events -
Figure 6. Agency model for rapid and longterm change in Central Anatolia (> more; $<$ less).

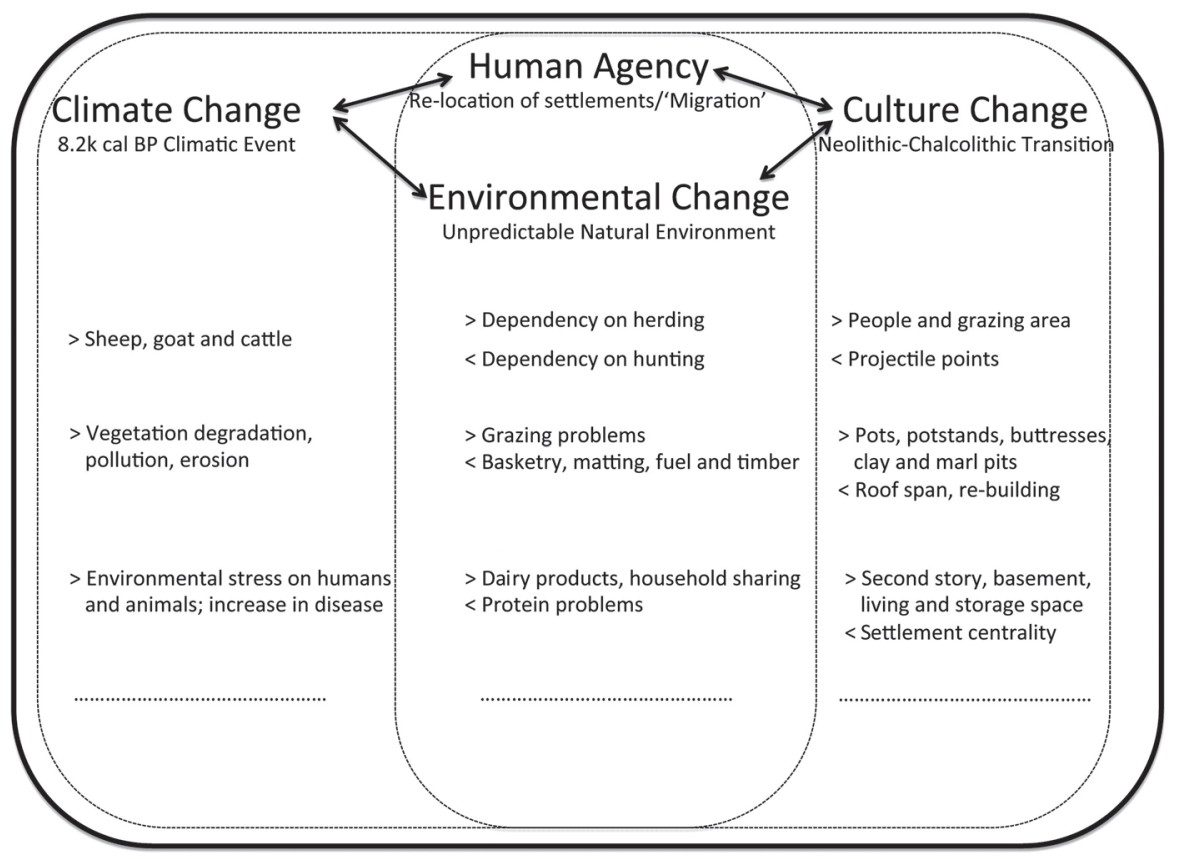


not only the climatic event - fundamentally changed the social organization, architecture, pottery and economy of the people at Çatalhöyük.

The existence of a settlement in Late Neolithic tradition on the East Mound contemporary with a settlement with so-called Early Chalcolithic material culture on the West Mound is a tempting model to integrate both continuity and change in two coexisting tells at Çatalhöyük. As we are only at the beginning of this part of the project this remains just a model, but the site will provide the possibility to examine how environmental change, economic innovation and social transformation starting around $6200 \mathrm{cal} \mathrm{BC}$ manifested itself in this central site of Central Anatolia.

\section{Approaching rapid and long term change in archaeology}

Marek Zvelebil saw long-term factors interacting with human agency in the short-term, and the Neolithic as a cultural shift in beliefs and attitudes, which can be explained by looking at people's worldview (Zvelebil 2005b). But we still seem to be left with a series of unresolved dichotomies: events versus centuries to millennia; rapid change versus long-term change; social and cultural factors versus environmental, demographic and economic factors; and agency versus functionalism. I would agree with Zvelebil that the agency view of the short as well as the long time-scale is crucial to better understand the past. Agency works with change and continuity and stability as both are generated by people with traditions of the past and intentions for the better life in the future. Humans certainly use the past to cope with challenges in the present such as rapid or gradual demographic or environmental changes, and we can study the actions intended or unintended and accidental - as represented in the archaeological record. "In each moment of history humans act culturally in conditions inherited from the past" (Sherratt 2000), and these conditions - climate, landscapes, resources, populations, technologies - are the result of human actions in past conditions. And to end with Andrew Sherratt's words "archaeology has two unique resources: its access to the microstructures of daily life, the pattern of 'small things forgotten' (Deetz 1977), and its ability to survey the grand sweep - 10.000 times the length of Braudel's longue durée. The question 'what happened in prehistory' can be answered both at the small scale of the petites histoires of objects and occupation levels, and at the level of grand recit of larger themes. Archaeology's objective should be to link these two domains, neglecting neither the one nor the other" (Sherratt 1993, 128).

\section{Acknowledgements}

In memoriam of Marek, a dear friend and irreplaceable researcher. I also would like to thank the Çatalhöyük West Mound Team and especially Eva Rosenstock.

\section{References}

AUDOUSE, F. and VALENTIN, B. 2010: A Paleohistorical Approach to Upper Paleolithic Structural Changes. In: Bolender, D. J. (Ed.), Eventful Archaeologies. New Approaches to Social Transformation in the Archaeological Record. Distinguished Monograph Series of the Institute for European and Mediterranean Archaeology Vol 1. SUNY Press, New York, 29-47.

BAIRD, D. 2002: Early Holocene settlement in Central Anatolia: problems and prospects as seen from the Konya Plain. In: Gérard, F., Thissen, L. (Eds.): The Neolithic of Anatolia. Internal developments and external relations during the 9th - 6th millennia cal BC. Ege Yayınlar1, Istanbul, 139-159.

BAIRD, D. 2006: The history of settlement and social landscapes in the Early Holocene in the Çatalhöyük area. In: Hodder, I. (Ed.): Çatalhöyük Perspectives: Themes from the 1995-1999 Seasons. McDonald Institute, Cambridge, 55-74.

BARKER, G. 2010: Archaeology and the Human Career. Revolutions, Transformations, Events. In: Bolender, D. J. (Ed.): Eventful Archaeologies. New Approaches to Social Transformation in the Archaeological Record. Distinguished Monograph Series of the Institute for European and Mediterranean Archaeology Vol 1. SUNY Press, New York, 219-236.

BARTL, K., in press: The Late Neolithic Site of Shir in Western Syria: The final Phase of Occupation around 6000 BC. In: Biehl, P. F., Nieuwenhuyse, O. (Eds.): Climate and Cultural Change in Prehistoric Europe and the Near East. Distinguished Monograph Series of the Institute for European and Mediterranean Archaeology. SUNY Press, New York.

BAYLISS, A., BRONK RAMSEY, C., VAN DER PLICHT, J., WHITTLE, A. 2007: Bradshaw and Bayes: towards a timetable for the Neolithic, Cambridge Archaeological Journal 17, 1-28.

BIEHL, P. F. 2012: From Mega-Site to Mega-Region: Çatalhöyük and the Konya Plain at the turn of the $6^{\text {th }}$ millennium BC. In: Matthews, R. (Ed.): Mega-cities and Mega-sites. Proceedings of the the $7^{\text {th }}$ International Congress on the Archaeology of the Ancient Near East (7ICAANE), 12.16. April 2010. Harrassowitz Verlag, London - Wiesbaden, 17-33.

BIEHL, P. F., in press: Climate and Social Change during the Transition between the Late Neolithic and Early Chalcolithic in Central Anatolia. In: Kerner, S., Dann, R., Bangsgaard Jensen, P. (Eds.): Ancient Society and Climate. Copenhagen University Press, Copenhagen.

BIEHL, P. F., ROSENSTOCK, E. 2009: Von Çatalhöyük Ost nach Çatalhöyük West: Kulturelle Umbrüche an der Schwelle vom 7. zum 6. Jahrtausend cal BC in Zentralanatolien. In: Einicke, R. (Ed.): Zurück zum Gegenstand. Festschrift für Andreas E. Furtwängler. Schriften des Zentrums für Archäologie und Kulturgeschichte des Schwarzmeerraumes 16. Beier \& Beran, Weissbach, 471-481.

BIEHL, P. F., FRANZ, I., OSTAPTCHOUK, S., ORTON, D., ROGASCH, J., ROSENSTOCK, E. 2012: One Community and Two Tells: The Phenomenon of Relocating Tell Settlements at the Turn of the $7^{\text {th }}$ and $6^{\text {th }}$ Millennia in Central Anatolia. In: Müller, J. (Ed.): Socio-Environmental Dynamics over the last 12,000 Years: The Creation of Landscapes. Offa, Kiel, 53-66.

BIEHL, P. F., ROSENSTOCK, E. 2012: Times of Change: a Short Report on the International Conference at the Free University Berlin, TOPOIBuilding, November 24-26, 2011, Neo-Lithics 2/11, 30-32.

BOLENDER, D. J. 2010: Toward an Eventful Archaeology. In: Bolender, D. J. (Ed.): Eventful Archaeologies. New Approaches to Social Transformation in the Archaeological Record. Distinguished Monograph Series of the Institute for European and Mediterranean Archaeology Vol 1. SUNY Press, New York, 3-16.

BOYER, P., ROBERTS, R., BAIRD, D. 2006: Holocene Environment and Settlement on the Çarşamba Alluvial Fan, South-Central Turkey: Integrating Geoarchaeology and Archaeological Field Survey, Geoarchaeology Vol. 21, 7, 675-698.

BRAUDEL, F. 1969 : Ecrits sur l'histoire. Flammarion, Paris.

CANEVA, I., in press: Mersin-Yumuktepe in the seventh millennium BC: the Social Dimension of Technological Changes. In: Biehl, P. F., Nieuwenhuyse, O. (Eds.): Climate and Cultural Change in Prehistoric Europe and the Near East. Distinguished Monograph Series of the Institute for European and Mediterranean Archaeology. SUNY Press, New York. 
LE BRUN, A., DAUNLE-LE BRUN, O. AND HOURANI, F., in press Chaning with the years: Khirokitia (Cyprus) at the turn of the seventh-sixth millennium BC. In: Biehl, P. F., Nieuwenhuyse, O. (Eds.): Climate and Cultural Change in Prehistoric Europe and the Near East. Distinguished Monograph Series of the Institute for European and Mediterranean Archaeology. SUNY Press, New York.

DOBRES, M. A., ROBB, J. E. 2005: "Doing" Agency: Introductory Remarks on Methodology, Journal of Archaeological Method and Theory 12/3, 159-166.

DÜRING, B. S., MARCINIAK, A. 2006: Households and communities in the central Anatolian Neolithic, Archaeological Dialogues 12 (2), 165187.

DÜRING, B. S. 2010: The Prehistory of Asia Minor. From Complex Hunter-Gatherers to Early Urban Societies. Cambridge University Press, Cambridge.

FRENCH, D. 1998: Canhasan sites 1. Canhasan I: Stratigraphy and structures. British Institute of Archaeology at Ankara Monograph No. 32, London.

HODDER, I. 2006: Çatalhöyük, the Leopard's Tale: Revealing the Mysteries of Turkey's Ancient town. Thames \& Hudson, London.

HODDER, I. 2010: Human-thing entanglement: towards an integrated archaeological perspective, Journal of the Royal Anthropological Institute (N.S.) 17, 154-177.

HODDER, I. 2011: Wheels of Time: Some Aspects of Entanglement Theory and the Secondary Products Revolution, Journal of World Prehistory 24 2-3, 175-188.

KRISTIANSEN, K., LARSSON, T. B. 2007: The Rise Of Bronze Age Society: Travels, Transmissions and Transformations. Cambridge University Press, Cambridge.

CESSFORD, C., LAST, J., GIBSON, C., in press: Central Anatolia in 6000 cal BC: dating Çatalhöyük West.

NIEUWENHUYSE, O., in press: Containers of Change: Social and Material Innovation in $7^{\text {th }}$ Millennium Upper Mesopotamia. In: Biehl, P. F., Nieuwenhuyse, O. (Eds.): Climate and Cultural Change in Prehistoric Europe and the Near East. Distinguished Monograph Series of the Institute for European and Mediterranean Archaeology. SUNY Press, New York.

MARCINIAK, A., CZERNIAK, L. 2007: Social transformations in the Late Neolithic and the Early Chalcolithic periods in central Anatolia, Anatolian Studies 57, 2007, 115-130.
ROSENSTOCK, E. 2009: Tells in Südwestasien und Südosteuropa: Untersuchungen zur Verbreitung, Entstehung und Definition eines Siedlungsphänomens. Remshalden.

SAGONA, A., ZIMANSKY, P. E. 2009: Ancient Turkey. Routledge, London.

SHERRATT, A. 1993: The relativity of theory. In: Yofee, N., Sherratt, A. (Eds.): Archaeological Theory - who sets the agenda. Cambridge University Press, Cambridge, 119-130.

SHERRATT, A. 1995: Reviving the Grand Narrative: Archaeology and Long-Term Change, Journal of European Archaeology, 3.1., 1-32.

SHERRATT, A. 1997: Climatic cycles and behavioural revolutions. The emergence of modern humans and the beginning of farming, Antiquity 71, 271-287.

SHERRATT, A. 2000: Envisioning global change: A long-term perspective. In: Denemark, R. A., Friedman, J., Gills, B. K., Modelski, G. (Eds.): World System History: the social science of long-term change. Routledge, London/New York, 115-132.

WENINGER, B. et al. 2005: Die Neolithisierung von Südosteuropa als Folge des abrupten Klimawandels um 8200 cal BP. In: Gronenborn, D. (Ed.): Klimaveränderungen und Klimawandel in neolithischen Gesellschaften Mitteleuropas, 6 700-2 200v. Chr. Römisch-Germanisches Zentralmuseum Mainz, RGZM-Tagungen 1, Mainz 2005, 75-118.

WHiTtle, A., BAYLISS, A., HEALY, F. 2010: Event and ShortTerm Process: Times for the Early Neolithic of Southern Britain. In: Bolender, D. (Ed.): Eventful Archaeologies. New Approaches to Social Transformation in the Archaeological Record. The Institute for European and Mediterranean Distinguished Monograph Series Vol.1. SUNY Press, New York, 68-87.

WHITTLE, A., HEALY, F., BAYLISS, A. (Eds.) 2011: Gathering time: Dating the Early Neolithic enclosures of southern Britain and Ireland. Oxbow Books, Oxford.

ZVELEBIL, M. 2005a: Book Review: Looking back at the Neolithic transition in Europe, European Journal of Archaeology 8/2, 183-190.

ZVELEBIL, M. 2005b: Homo habius: agency, structure and transformation of tradition in the constitution of the TRB foraging-farming communities in the North European plain (ca. 4500-2000 BC), Documenta Praehistorica XXXII, 87-101. 
